\title{
Haematological, biochemical and histological characteristics of broiler chickens fed graded levels of dry distilled cassava with soluble
}

Oyedele, O. J., Ajibogun, F. H. A., Otunla, T. A. and Olosunde, A. O.

Bioresources Development Centre Ogbomoso,

National Biotechnology Agency, Abuja

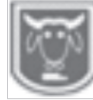

Klm 5, Iresaapa/Ogbomoso Road, Onipanu, Ogbomoso,

Oyo State, Nigeria

*Corresponding author: mrbgodveng@gmail.com

Abstract

This study was carried out to determine the haematological, biochemical and histological characteristics of broiler chickens fed graded levels of Dry Distilled Cassava with Soluble (DDCS). In a 28-day trial, one hundred and forty four (144) 5-week old, mixed Arbor Acre strain broiler chicks (average weight of $1.09 \pm 0.02 \mathrm{~kg}$ ) were randomly allocated to four dietary treatments of (0\% DDCS, 4\% DDCS, 8\% DDCS and 12\% DDCS) in completely randomized design. Each treatment had 2 replicates of 18 birds each. Feed and water were supplied ad libitum. Four birds from each treatment were randomly selected and blood sample collected via jugular puncture for haematological and biochemical evaluation at the termination of experiment. The analysis of blood components, red blood cell (RBC), white blood cell (WBC), packed cell volume (PCV), Mean cell volume (MCV), Mean corpusclar haemoglobin concentration (MCHC) and Mean cell haemoglobin (MCH) showed no significant $(P>0.05)$ differences among the broilers fed with experimental diets. There were no significant $(P>0.05)$ differences in the biochemical analysis of the broilers fed different levels of DDCS. Three birds were randomly selected from each treatment group and slaughtered for carcass evaluation and histological analysis of small intestine, kidney, spleen, liver and large intestine. It was concluded that DDCS can be included in the diets of broilers up to $12 \%$ without any deleterious effect on the haematological and serum biochemical characteristics. The feeding of DDCS to poultry at 4, 8, and 12\% resulted in liver, kidney, small intestine and large intestine changes.

Keywords: Haematological, biochemical, histology, dry distilled cassava with soluble, broiler chicks

\section{Des Caractéristiques hématologiques, biochimiques et histologiques des poulets à griller nourris à des niveaux classés de manioc distillé sec avec soluble (DDCS)}

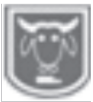

Résumé

Cette étude a été réalisée pour déterminer les caractéristiques hématologiques, biochimiques et histologiques des poulets de gril nourris à des niveaux classés de manioc distillé sec avec soluble (DDCS). Au cours d'un essai de 28 jours, cent quarante-quatre (144)

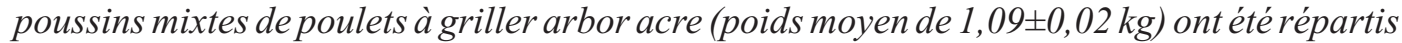
au hasard à quatre traitements diététiques de (0\% DDCS, 4\% DDCS, 8\% DDCS et 12\% $D D C S)$ dans un design complètement randomisé. Chaque traitement avait 2 répliques de 18 oiseaux chacun. L'alimentation et l'eau ont été fournies ad libitum. Quatre oiseaux de chaque traitement ont été choisis au hasard et un échantillon de sang prélevé par perforation jugulaire pour une évaluation hématologique et biochimique à la fin de l'expérience. L'analyse des composants sanguins, des globules rouges (RBC), des globules blancs (WBC), 
$d u$ volume cellulaire emballé (PCV), du volume moyen des cellules (MCV), de la concentration moyenne de corpusclar haemoglobine (MCHC) et de l'hémoglobine à cellules moyennes (HME) n'a montré aucune différence significative $(P>0,05)$ entre les poulets de grillage nourris avec des régimes expérimentaux. Il n'y avait aucune différence significative $(P>0,05)$ dans l'analyse biochimique des poulets de grillage nourris à différents niveaux de DDCS. Trois oiseaux ont été choisis au hasard dans chaque groupe de traitement et abattus pour l'évaluation des carcasses et l'analyse histologique de l'intestin grêle, du rein, de la rate, du foie et du gros intestin. Il a été conclu que le DDCS peut être inclus dans les régimes des poulets de grillage jusqu'à 12\% sans aucun effet délétère sur les caractéristiques biochimiques hématologiques et sériques. L'alimentation du DDCS aux volailles à 4 , 8 et 12 \% a entraîné des changements dans le foie, les reins, l'intestin grêle et les gros intestins.

Mots-clés: Hématologique, biochimique, histologie, manioc distillé sec avec soluble, poussins de poulets de gril

\section{Introduction}

Despite the enormous improvement that has been achieved in the area of poultry production globally, it is still exigent to constantly push the boundary in sustainable poultry production as global population continues to grow exponentially. Increased human population and activity has not only put pressure on global food resources but also on the environment, which includes waste production and management. Therefore, research for alternative animal feed sources that is non-competitive with human feed, cost effective and environmentally sustainable for livestock production is a continuum. In recent times as Nigeria advocates the use of alternative and sustainable fuel source, it is important to proactively research into the potential use of the waste product that will result from this industry. Hence the need to research into alternative and sustainable poultry feed for ultimate performance, improved productivity and general carcass quality; it is essential to also consider the effects these unconventional feeds such as DDCS - a waste product from the fermentation and distillation process of cassava in ethanol production will exert on the blood and serum characteristics of the animals (Mahmud et al., 2016). Dry distilled product with soluble is obtained from the fermentation process of alcohol distillation, from raw materials rich in carbohydrates and sugars such as molasses or juices of sugarcane, maize, beet, among others, and with the usage of yeasts (Trautwein et al., 2008). Due to the fermentation process, the by-product such as vinasse is said to be high in organic acid which is reported to be a better substitute for antibiotics in improving growth performance and intestinal health morphology of birds (Mohamed et. al., 2014) this makes DDCS a promising component of animal and poultry feed. Adenkola et al. (2011) reported that dietary constituents have measurable effects on blood components and blood constituents are widely used in nutritional evaluation and survey of animals. Blood biochemical analysis can assist the monitoring of poultry health, the diagnosis and treatment of diseases, and asses their health status (Schmidt et al., 2007). This study therefore seeks to evaluate the effect of graded levels of DDCS on haematology, biochemical and histological characteristics of broilers.

\section{Materials and methods \\ Study area}

The experiment was conducted at the poultry section of the Bioresources Development Centre (BIODEC), Ogbomoso. It lasted for four weeks (28 days). The DDCS used in this study was obtained from Bio-ethanol Production plant 
of National Biotechnology Development Agency (NABDA), located in BIODEC, Onipanu, Ogbomoso, Nigeria.

\section{Processing of DDCS}

The samples were collected from production plant stored in tank using the outlet faucet (hose) of the storage tank. There were collected into jute bags; the water was allowed to drain out then sundried for two days. The processed samples were stored in a sack at room temperature prior to proximate analysis by standard methods (AOAC, 1990).

\section{Experimental diets}

Four dietary treatments were formulated with $0,4,8$ and $12 \%$ DDCS inclusion (Table 1). One hundred and forty-four (144), 5weeks un-sexed Arbor acre strain broiler chicks were used. The birds were randomly allotted to four dietary treatments in a completely randomized design. Each treatment had 2 replicates of 18 birds each. The mean initial weight was $1.09 \mathrm{~g}$.

Table 1: Composition of experimental diets

\begin{tabular}{lllll}
\hline Ingredients & $0 \%$ DDCS & $4 \%$ DDCS & $8 \%$ DDCS & $12 \%$ DDCS \\
\hline Maize & 54.75 & 54.75 & 54.75 & 54.75 \\
Soybean meal & 28.00 & 28.00 & 28.00 & 28.00 \\
Wheat offal & 12.00 & 8.00 & 4.00 & - \\
DDCS & - & 4.00 & 8.00 & 12.00 \\
Bone Meal & 3.00 & 3.00 & 3.00 & 3.00 \\
Oyster shell & 1.50 & 1.50 & 1.50 & 1.50 \\
Salt & 0.20 & 0.20 & 0.20 & 0.20 \\
Vitamin Premix & 0.25 & 0.25 & 0.25 & 0.25 \\
Lysine & 0.15 & 0.15 & 0.15 & 0.15 \\
Methionine & 0.15 & 0.15 & 0.15 & 0.15 \\
\hline Total & 100.00 & 100.00 & 100.00 & 100.00 \\
Calculated \% CP & 19.65 & 19.71 & 19.41 & 19.10 \\
Metabolizable energy & $2,874.22$ & $2,789.42$ & $2,714.62$ & $2,639.82$ \\
(Kcal/Kg) & & & & \\
Crude fibre (\%) & 3.73 & 4.97 & 6.17 & 7.38 \\
\hline
\end{tabular}

Haematological and biochemical characteristics

At the end of the feeding trial, the birds were fasted for twelve (12) hours and the birds weighed and slaughtered by severing the jugular vein of four birds randomly selected from each treatment group to assess blood profile of the birds. The blood was then allowed to flow freely into labeled bijou bottles one of which contained a speck of EDTA while the others were without EDTA. The blood in the EDTA-containing bijou bottles was processed for haematology while those in bottles without EDTA were processed for biochemical analysis. The blood samples immediately after collection were taken to the laboratory in the Department of Chemical Pathology,

Ladoke Akintola University of Technology (LAUTECH) Teaching Hospital Ogbomoso for the determination of haematological and biochemical characteristics. Packed cell volume (PCV), red blood cell (RBC), white blood cell (WBC) counts, Mean cell volume (MCV), Mean corpusclar haemoglobin concentration (MCHC) and Mean cell haemoglobin $(\mathrm{MCH})$ were determined (Baker and Silverton, 1976). Blood samples for serum analysis after clotting, was centrifuged at 3,500 rpm in the laboratory using Gallenkamp laboratory centrifuge in order to obtain the serum. The centrifugation was carried out according to Mitruka and Rawnsley (1977) procedure. The serum obtained was used in 
determining creatinine, total protein, glucose, bilirubin, alkaline phosphatase, cholesterol, albumin and urea according to Randox procedure of chemical analysis (2010).

\section{Histology}

At the end of the 28 day experimental period the birds were fasted for a period of 12 hours, 3 birds each were randomly selected from each treatment group. The birds were de-feathered and eviscerated, and a section of representative tissue samples from small intestine, kidney, spleen, liver and large intestine were fixed in neutral - buffered $10 \%$ formalin and processed using standard paraffin - embedding histopathology techniques as described by Bancroft and Gamble (2008). The formalinized tissues were dehydrated in 4 grades of alcohol, cleared in 3 xylene grades and embedded in molten wax. The embedded tissues were then trimmed into blocks and $5 \mu \mathrm{m}$ tissue samples were sectioned from the blocks using a microtome. The sections were floated in a water bath and incubated at $60^{\circ} \mathrm{C}$ for 30 minutes. Staining was carried out by first clearing the section in 3 grades of xylene and rehydrating in 2 grades of alcohol. The sections were put into water and stained with hematoxylin for 15 minutes. Bluing was done with Ammonium chloride; differentiation in $1 \%$ acid alcohol was done before counterstaining with eosin. The stained slides were then mounted on glass slides using DPX (Distrene, Plasticiser and Xylene) a non-aqueous permanent mountant.

\section{Statistical analysis}

Data obtained were subjected to analysis of variance (ANOVA) using SAS Statistical Package, SAS 2008. The means were separated using Duncan's multiple range test.

\section{Results and discussion}

The composition and chemical composition of experimental diets with different inclusion levels of DDCS are as shown in Table 1 and 2, respectively. The crude protein and crude fibre content increased with increase in the inclusion level of DDCS. The crude protein range was 25.81$26.25 \%$. The results of the haematological parameters of broiler chickens fed different levels of DDCS are presented in Table 3. The analysis of haemological parameters showed that there were no significant $(\mathrm{P}>0.05)$ differences among the broilers fed experimental diets.

Haemological parameters are usually related to health status and are of diagnostic importance in clinical evaluation of the state of health. It serves as indicator of physiological, pathological and nutritional status of an animal (Okoruwa and Ikhimioya, 2014). It has been established that certain haematological parameters are associated with certain production traits in chickens, for example, high packed cell volume (PCV) and high haemoglobin $(\mathrm{Hb})$ are indicators of high feed conversion ratio

Table 2: Chemical composition of diets fed to experimental broiler chickens

\begin{tabular}{|c|c|c|c|c|}
\hline Parameter & $0 \%$ DDCS & $4 \%$ DDCS & $8 \%$ DDCS & $12 \% \mathrm{DDCS}$ \\
\hline $\begin{array}{l}\text { Dry matter (DM) } \\
\text { Analysis \% of DM }\end{array}$ & 93.18 & 92.94 & 93.49 & 93.33 \\
\hline Organic matter & 88.85 & 92.61 & 91.04 & 89.56 \\
\hline Crude protein & 25.81 & 26.25 & 26.25 & 26.25 \\
\hline Crude fibre & 2.49 & 3.29 & 3.93 & 4.70 \\
\hline Ether extract & 3.72 & 4.29 & 4.27 & 3.43 \\
\hline Ash & 13.15 & 7.39 & 8.96 & 10.44 \\
\hline Nitrogen free extract & 48.01 & 51.72 & 50.08 & 48.51 \\
\hline
\end{tabular}


Table 3: Haematological parameters of broiler chickens fed graded levels of dry distilled cassava with soluble

\begin{tabular}{lllllll}
\hline Parameter & $0 \%$ DDCS & $4 \%$ DDCS & $8 \%$ DDCS & $12 \%$ DDCS & SEM & PROB \\
\hline WBC $\left(\times 10^{9} / \mathrm{L}\right)$ & 109.98 & 106.23 & 105.98 & 101.50 & 2.44 & 0.74 \\
RBC $\left(\mathrm{x} 10^{12} / \mathrm{L}\right)$ & 2.33 & 2.14 & 2.11 & 2.23 & 0.04 & 0.14 \\
PCV $(\%)$ & 30.25 & 30.33 & 29.75 & 31.33 & 0.71 & 0.92 \\
MCV $(\mathrm{fl})$ & 119.38 & 121.03 & 121.93 & 122.93 & 0.65 & 0.26 \\
MCHC $(\mathrm{g} / \mathrm{dL})$ & 7.28 & 7.40 & 7.98 & 7.03 & 0.28 & 0.71 \\
MCH $(\mathrm{pg})$ & 8.95 & 8.00 & 10.64 & 8.80 & 0.43 & 0.14 \\
\hline \multicolumn{2}{c}{$, \mathrm{b}, \mathrm{c}, \mathrm{d}$ : Means within each row with different superscript are significantly different $(\mathrm{p}<0.05)$} \\
SEM = Standard error of mean, PROB = Probability
\end{tabular}

while high serum protein is an indicator of good feathering ability and tissue growth in chickens (Nyaulingo, 2013). Authors (Aletor et al., 1989; Aletor and Egberongbe (1992) previous studies showed that blood variables that are most commonly affected by dietary treatments include packed cell volume (PCV) and red blood cell (RBC). Oyelola et al., 2004 also reported that decreased RBC is usually associated with low quality feed and protein deficiency. The WBC counts $\left(\mathrm{x} 10^{9} / \mathrm{L}\right)$ from this study were $101.50,105.98,106.23$ and 109.98 for $12 \%$ DDCS, $8 \%$ DDCS, $4 \%$ DDCS and $0 \%$ DDCS respectively. High WBC count is usually associated with microbial infection or the presence of a foreign body or antigen in the circulating system. The values obtained for WBC were within normal range for broilers reported by (Ahiwe et al., 2014). The result showed that RBC counts range was $2.11-2.23\left(\times 10^{12} / \mathrm{L}\right)$. The RBC range was in line with range 1.8-2.4 obtained by Zanu et al., 2012 but lower than range of 3.08-3.20 reported by Owosibo et al., 2013. The PCV range from this study is in line with PCV range of 25.67-31.00 and 20.00-32.00 reported by Ari and Ayanwale (2014) and Iyayi et al., 2005 respectively. In this experiment, all the blood parameters fell within the normal range reported by Pampori (2003). The MCV (fl) obtained was lower than the range (128.0-135.3) reported by Adeyemo and Sani (2013) but in line with 92.44-122.09 reported by Akinola and
Ethuk (2015). The non-significant differences $(P>0.05)$ in the values of the haematological parameters compare to the values observed for the control shows that there is no deleterious effect of the inclusion of DDCS at different levels on the serum parameters. Serum biochemistry is a liable biochemical system which can reflect the condition of the organism and the changes happening to it under influence of internal and external factors (Toghyani et al., 2010). The results of the serum metabolites of broiler chicken fed graded levels of DDCS are shown in Table 4. There were no significant $(\mathrm{P}>0.05)$ differences in the serum metabolites of broiler chickens fed different levels of DDCS $(\mathrm{P}>0.05)$. Serum proteins are mainly synthesized in the liver and plays important functions such as maintain blood volume through the colloidal osmotic effect, buffer blood $\mathrm{pH}$, transport hormones and drugs, participate in cell coagulation and in the body defense against foreign agents, catalyze chemical reactions (enzymes) and regulate the metabolism (hormones) (Melillo, 2013). According to Harr et al. (2002), serum total protein values of broilers tend to be lower than those of mammals, ranging from 25.00 to $45.00 \mathrm{~g} / \mathrm{L}$. Melillo, 2013 reported that the main functions of albumin are the transport of several molecules and the maintenance of blood oncotic pressure. The values of albumin from this study was within the 


\section{Haematological, biochemical and histological characteristics of broiler chickens}

Table 4 : Serum metabolites of broiler chickens fed graded levels of dry distilled cassava with soluble

\begin{tabular}{|c|c|c|c|c|c|c|}
\hline Parameter & $0 \%$ DDCS & $4 \%$ DDCS & $8 \%$ DDCS & $12 \%$ DDCS & SEM & PROB \\
\hline Total protein $(\mathrm{g} / \mathrm{l})$ & 34.50 & 38.33 & 33.25 & 30.00 & 1.31 & 0.28 \\
\hline Albumin (g/l) & 9.28 & 10.70 & 10.93 & 13.13 & 0.65 & 0.24 \\
\hline Globulin $(\mathrm{g} / \mathrm{l})$ & 25.23 & 27.63 & 22.33 & 16.90 & 1.43 & 0.10 \\
\hline Creatinine (umol/l) & 46.25 & 71.33 & 61.00 & 51.00 & 5.39 & 0.42 \\
\hline $\mathrm{AST}(\mathrm{IU} / \mathrm{L})$ & 87.25 & 87.00 & 92.75 & 84.33 & 2.25 & 0.65 \\
\hline ALT (IU/L) & 1.83 & 2.57 & 1.88 & 2.73 & 0.37 & 0.80 \\
\hline $\begin{array}{l}\text { Cholesterol } \\
(\mathrm{mmol} / \mathrm{L})\end{array}$ & 2.40 & 2.63 & 2.30 & 2.83 & 0.09 & 0.15 \\
\hline $\begin{array}{l}\text { Tryglyceride } \\
(\mathrm{mmol} / \mathrm{L})\end{array}$ & 0.43 & 0.27 & 0.43 & 0.23 & 0.04 & 0.26 \\
\hline $\mathrm{HDL}(\mathrm{mmol} / \mathrm{L})$ & 1.80 & 1.87 & 1.75 & 2.10 & 0.06 & 0.23 \\
\hline LDL (mmol/L) & 0.41 & 0.67 & 0.35 & 0.63 & 0.07 & 0.24 \\
\hline Uric acid (mmol/L) & 0.48 & 0.38 & 0.46 & 0.35 & 0.03 & 0.47 \\
\hline
\end{tabular}

range values of 11.80 to $15.60 \mathrm{~g} / \mathrm{L}$ for female broilers and 8.70 to $12.50 \mathrm{~g} / \mathrm{L}$ for male broilers reported by Rezende et al. (2017) and normal albumin values for broilers reported by Meluzzi et al. (1992). AST values were between 84.33 and 92.75 IU/L. The values of AST were greater than the range of 13.72-15.65 reported by Akinola and Etuk, 2015. The nonsignificant differences $(\mathrm{P}>0.05)$ in the values of the serum parameters compare to the values observed for the control shows that there is no deleterious effect of the different inclusion of DDCS at different levels on the serum parameters. The study of different enzyme activities such as ALT, AST and total protein have been found to be of great value in the assessment of clinical and experimental liver damage (Olawale, 2019). High levels of ALT indicates liver injury while the rise in the AST is usually accompanied by an elevation in the levels of ALT, which plays a vital role in the conversion of amino acids to keto acids (Hoffbrand and Pettit, 1997; Dash et al., 2007). The uric acid values of 0.38-0.46 $\mathrm{mmol} / \mathrm{L}$ for broilers obtained from this study is in line with the range between 0.12 and $0.89 \mathrm{mmol} / \mathrm{L}$ reported by Benez (2004).
The cholesterol range of 2.30-2.83 mmol/L from this study was within the cholesterol values of 2.63-3.48 $\mathrm{mmol} / \mathrm{L}$ reported by Abdulazeez et al., 2016 for broilers. Triglycerides are synthesized in the intestinal mucosa and in the liver from the digestion of dietary components and the absorption of fatty acid (Rezende et al., 2017). Triglyceride range (0.23-0.43 $\mathrm{mmol} / \mathrm{L}$ ) from this study was less than 1.54$1.88 \mathrm{mmol} / \mathrm{L}$ reported by Evans et al. (1977) for broilers fed diet with around 3,000 Kcal metabolizable energy/kg but lower than $0.23-0.28 \mathrm{mmol} / \mathrm{L}$ obtained by Osorio et al . (2012) for broilers fed diet containing 18\% crude protein and $3150 \mathrm{Kcal}$ metabolizable energy $/ \mathrm{kg}$. Cholesterol travels in the blood as particles called lipoprotein is an important constituent of cell membranes modulating their fluidity; it is a precursor of steroid hormones (Kasprzak and Hetmañski, 2004). Total Cholesterol is made up of low-density Lipoproteins (LDL), high-density Lipoprotein (HDL) and very low density Lipoprotein (VLDL). There are two known facts that Cholesterol must be in the rancid form to cause the arterial plaques that lead to partial blockage of the blood vessels while some forms of 
Cholesterol are beneficial to man. High density Lipoprotein (HDL) has been established to protect against heart disease by mopping up circulating Cholesterol units in the system (Narahari, 2003). The culprit responsible for this oxidized form that narrows or "hardens" the arteries is the lowdensity Lipoprotein Cholesterol (LDL) and low levels of the HDL fraction (Kasprzak and Hetmañski, 2004). Table 5 shows the histopathological changes observed in selected organs of broiler chickens fed with graded levels of DDCS. There were no changes observed in the spleen of the experimental birds. The result shows that there were histological changes in the small intestine, liver, kidney and large intestine of birds fed $4 \%, 8 \%$ and $12 \%$ DDCS. This is probably caused by the inclusion of DDCS in the experimental diet. The histopathological changes observed indicate that incorporation of DDCS in broiler feed could cause adverse effects associated with changes in the small intestine, kidney, liver and large intestine. Contrary to report by Mohamed et al. (2014) that organic acids improved the intestinal morphology of birds, the high organic acid content in DDCS did not improve the intestinal morphology of the experimental birds in this study.

Table 5: Histopathological changes in selected organs of broiler chickens feed with graded levels of DDCS

\begin{tabular}{|c|c|c|c|c|}
\hline Tissue & $0 \%$ DDCS & $4 \%$ DDCS & $8 \%$ DDCS & $12 \%$ DDCS \\
\hline $\begin{array}{l}\text { Small } \\
\text { intestine }\end{array}$ & $\begin{array}{l}\text { No visible } \\
\text { lesion }\end{array}$ & $\begin{array}{l}\text { Matting, loss of } \\
\text { villi and } \\
\text { hyperplasia of } \\
\text { the mucosal } \\
\text { gland in the } \\
\text { lamina propria }\end{array}$ & $\begin{array}{l}\text { Matting, clubbing } \\
\text { and sloughing off } \\
\text { of the villi }\end{array}$ & $\begin{array}{l}\text { Loss of villi and } \\
\text { lymphoid hyperplasia in } \\
\text { the lamina propria }\end{array}$ \\
\hline Kidney & $\begin{array}{l}\text { No visible } \\
\text { lesion }\end{array}$ & $\begin{array}{l}\text { Tubular epithelia } \\
\text { cell swelling and } \\
\text { degeneration }\end{array}$ & $\begin{array}{l}\text { Tubular epithelia } \\
\text { cell swelling and } \\
\text { degeneration }\end{array}$ & $\begin{array}{l}\text { Renal congestion and } \\
\text { tubular degeneration, }\end{array}$ \\
\hline Spleen & $\begin{array}{l}\text { No visible } \\
\text { lesion }\end{array}$ & No visible lesion & No visible lesion & No visible lesion \\
\hline Liver & $\begin{array}{l}\text { No visible } \\
\text { lesion }\end{array}$ & $\begin{array}{l}\text { Hepatic } \\
\text { congestion and } \\
\text { degeneration }\end{array}$ & $\begin{array}{l}\text { Hepatic } \\
\text { congestion and } \\
\text { degeneration }\end{array}$ & $\begin{array}{l}\text { Hepatic congestion and } \\
\text { degeneration }\end{array}$ \\
\hline $\begin{array}{l}\text { Large } \\
\text { intestine }\end{array}$ & $\begin{array}{l}\text { No visible } \\
\text { lesion }\end{array}$ & $\begin{array}{l}\text { Goblet cell } \\
\text { hyperplasia }\end{array}$ & $\begin{array}{l}\text { Goblet cell } \\
\text { hyperplasia and } \\
\text { edema in the } \\
\text { submucosa }\end{array}$ & $\begin{array}{l}\text { Loss of crypt and } \\
\text { sloughing off of } \\
\text { epithelia cells }\end{array}$ \\
\hline
\end{tabular}




\section{Haematological, biochemical and histological characteristics of broiler chickens}

Plates 1-4 below shows the histopathologic changes in the small intestine, kidney, liver and large intestine.
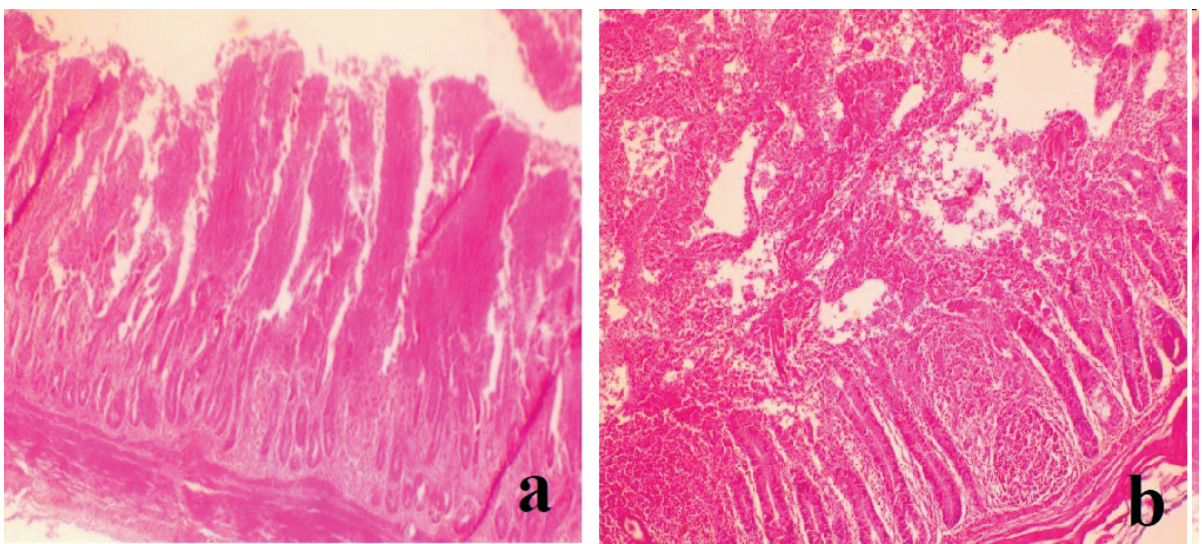

Plate 1a and b: Matting, loss of villi and hyperplasia of the mucosal gland in small intestine of birds fed 4 to $12 \%$ DDCS
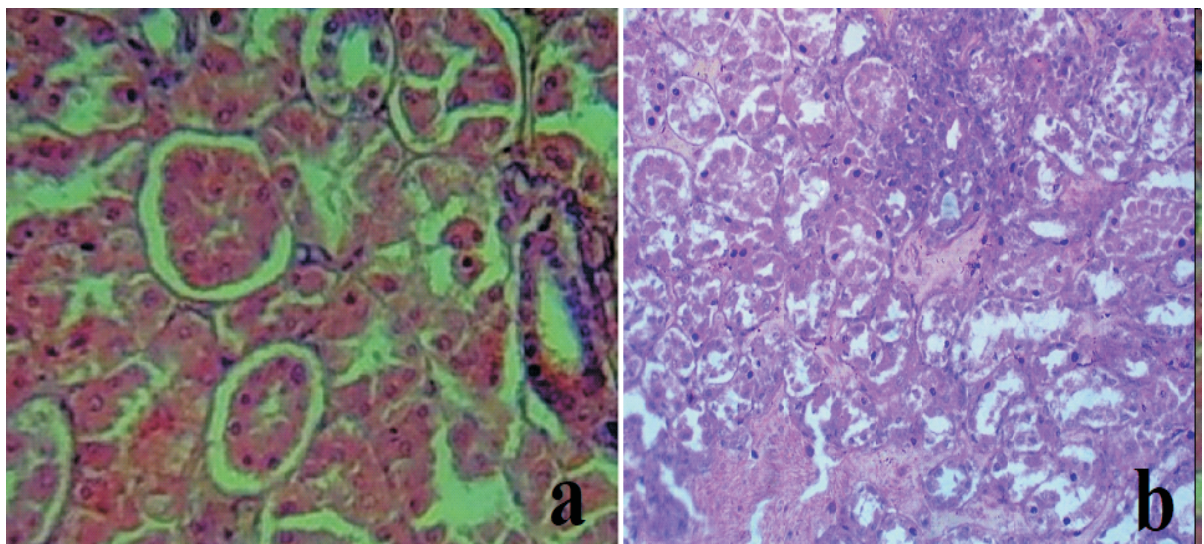

Plate 2a and b: Epithelial cell swelling and congestion of the renal tubules in birds fed 4 to $12 \%$ DDCS
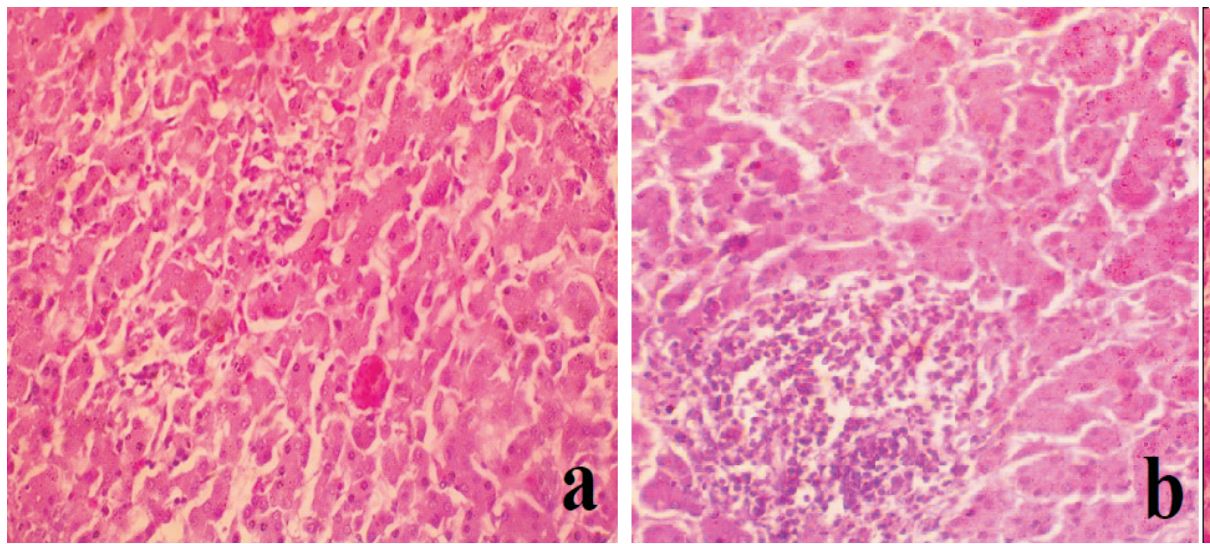

Plate 3a and b: Hepatic degeneration and necrosis in birds fed 4 to $12 \%$ DDCS 


\section{Oyedele, Ajibogun, Otunla and Olosunde}
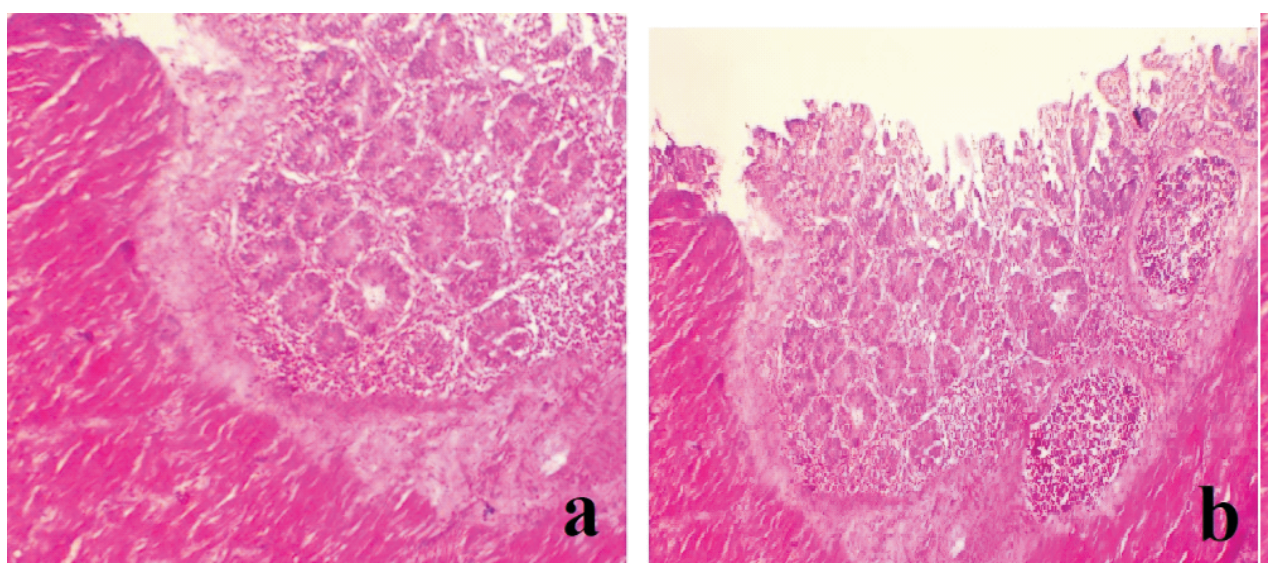

Plate 4a and b: Hyperplasia of goblet cell mucosal gland and loss of crypt in large intestine of birds fed 4 to $12 \%$ DDCS

\section{Conclusion}

From the results it can be concluded that DDCS can be included in the diet of broiler chickens up to $12 \%$ without any deleterious effect on the haematological and serum biochemical characteristics. Inclusion of DDCS in the diet of broiler chickens up to $4 \%$ can results in histological changes in the liver, kidney, small intestine and large intestine of the broilers which can be due to increase in crude fibre level in the diets as the inclusion of DDCS increases. Further study is however, required to ascertain the mechanism by which increased DDCS in feed causes the lesions as observed in the histology of the broilers.

\section{References}

Adenkola, A. Y., Idoga, E. S. and Tughgba, T. 2011. Comparative assessment of erythrocyte osmotic fragility and heamatological parameters of broiler and local chicken during the hot-dry season in Makurdi, Nigeria. Proceedings of $36^{\text {th }}$ Annual Conference of Nigerian Society of Animal Production, University of Abuja, Nigeria. pp 117-119.

Adeyemo, I. A. and Sani, A. 2013.
Haematological parameters and serum biochemical indices of broilers chicken fed Aspergillus niger hydrolyzed cassava peel meal based diet. International Journal of Recent Research Aspects, 15(3), pp 410-415.

Abdulazeez, Z. H., Adamu, S. B., Igwebuike, J. U. Gwayo, G. J. and Muhammad, A. I. 2016. Haematology and serum biochemistry of broiler chickens fed graded levels of baobab (Adansonia digitate L.) seed meal. IOSR Journal of Agriculture and Veterinary Science. 9(10):48-53.

Ahiwe, E. U., Emenalom, O. O., Etuk, E. B. and Okehie, U. N. 2014. Performance of 'Kaur' variety of sorghum (Sorghum bicolor) based diet supplemented with enyme. Nigeria Journal of animal science, 15(1), 75-82.

Akinola, L. A. and Etuk, M. O. 2015. Haematological and Serum Biochemical Responses of Broilers Fed Varying Levels of Indomie Waste-Based Diets. IOSR Journal of Agriculture and Veterinary Science (IOSR-JAVS), Vol. 8(1), 
Haematological, biochemical and histological characteristics of broiler chickens

pp 66-70.

Aletor, V. A., Agbede, J. O. and Sobondo, R. A. 1989. Heamatological and biological aspect of feeding broiler chicken conventional or underutilised protein resources. Proceeding of Silver Anniversary Conference of Nigerian Society for Animal Production and Inaugural Conference of World Poultry Science Association, Gateway Hotel, Abeokuta, Nigeria, 21-26 March, 1989, Paper No. 79.

Aletor, V. A. and Egberongbe, O. 1992. Feeding differently processes soyabeans. Part 2: An assessment of haematological responses in the chickens. Die Nahrung 36(4): 364369.

AOAC 1990. Official Method of Analysis. $15^{\text {th }}$ Edition, Association of Official Analytical Chemists, Washiington D.C., USA.

Ari, M. M. and Ayanwale, B. A. 2014. Serum Profile and Growth Indices of Broilers Fed Diets Containing Alkaline Treated Soyabeans. Asian Journal of Poultry Science, 8: 9-15.

Baker, F. J. and Silverton, R. E. 1976. Introduction to Medical Laboratory Technology, Butterworth \& Co. Ltd., 735pp.

Bancroft, J. D. and Gamble, M. 2008. Theory and Practice of Histological Techniques, Six Edition: Elisevier Health Sciences.

Benez, S. M. 2004. Aves: criação, clínica, teoria, prática: silvestres, ornamentais, avinhados. $4^{\mathrm{a}}$ ed. Ribeirão Preto: Tecmedd; 2004. p.332.

Dash, D. K., Yeligar, V. C., Nayak, S. S., Gosh, T. and Rajalingam, D. 2007 . Evaluation of hepatoprotective and antioxidant activity of Ichnocarpus frutescens (Linn.) on paracetamol-induced hepatotoxicity in rats. In: International journal of pharmacology, 4: 352-360.

Evans, A. J., Bannister, D. W., Whitehead, C. C., Siller, W. G. and Wight, P. A. 1977. Changes in plasma lipid and glucose levels during the onset of fatty liver and kidney syndrome in chicks. Research in Veterinary Science 1977; 23:275-279.

Harr. K. E. (2002). Clinical chemistry of companion avian species: a review. Veterinary Clinical Pathology 2002; 31(3):140-151.

Hoffbrand, A. V. and Pettit, J. E. 1997. Essentials of haematology. In: International journal of pharmacology, 4: 352-360.

Iyayi, E. A., Taiwo, V. O. and Fagbohun, A. O. 2005. Performance, carcass characteristics, haematological and histopathological studies of broilers fed Mucuna (Mucuna utilis) bean meal based diets. Israel Journal of Veterinary Medicine 60(2): 51-58.

Kasprzak, M. and Hetmanski, T. 2004. Plasma fat parameters in the feral pigeon (Columba livia f. urbana) during its postembryonic development. Zool. Polon., 49, 229-235.

Mahmud, M., Maidala, A., Dantata, I. J. and Turaki, H. 2016. Blood Profile and Serum Biochemical Parameters of Broiler Chickens Fed Three Local Sorghum Varieties Grown in Bauchi State. International Institute of Academic Research and Development, pp 35 40.

Melillo, A. 2013. Applications of serum protein electrophoresis in exotic pet medicine. Veterinary Clinics of North America Exotic Animal Practice 2013; 16(1):211-22. 
Meluzzi, A., Primiceri, G., Giordani, R. and Fabris G. 1992 . Determination of blood constituents reference values in broilers. Poultry Science, 71(2), 337-345.

Mitruka, B. M. and Rawnsley, H. M. 1977. Clinical biochemical and Hematological reference values in normal experimental animals, New York, Masson, pp: 100-200.

Mohamed, M. A., El-Daly, F. E., Abd ElAzeem, N. A., Youssef, W. A. and Hassan, H. M. A. 2014. Growth Performance and Histological Changes in Ileum and Immune Related Organs of Broilers Fed Organic Acids or Antibiotic Growth Promoter. International Journal of Poultry Science 13 (10) pp 602-610.

Narahari, D. 2003. Egg, Cholesterol, fat and healthy diet. Karnal, Haryana, India, Pixie Publications. 76 pp.

Nyaulingo, J. M. 2013. Effect of Different Management Systems on Haematological Parameters in Layer Chickens. A Dissertation Submitted in Partial Fulfilment of the Requirements for the Degree of Master of Science in Comparative Animal Physiology of Sokoine University of Agriculture, Morogoro, Tanzania.

Okoruwa, M. I. and Ikhimioya, I. 2014. Haematological Indices and Serum Biochemical Profiles of Dwarf Goats Fed Elephant Grass and Varying Levels of Combined Plaintain with Mango Peels. American Journal of Experimental Agriculture, 4, 6.

Olawale, M. A. 2019. Performance and Health implication of feeding Fungi treated cocoa pod husk meal on broiler. Bulletin ofthe National Research Centre 43, 55 (2019) doi:10.1186/s42269-019-0097-7

Osorio J. H., Flores-Ochoa, J. D. and Uribe-Velasquez, L. F. 2012. Comparación del perfil lipídico en dos líneas de pollos de engorde. Revista Científica 2012;22(6):553559.

Owosibo, A. O., Odetola, O. M., Odunsi, O. O., Adejinmi, O. O. and Lawrence-Azua, O. O. 2013. Growth, haematology and serum biochemistry of broilers fed probiotics based diets, African Journal of Agricultural Research, Vol. 8(41), pp. 5076-5081.

Oyelola, B. O., Otunola, G. A. and Apata, D. F. 2004. Assessment of protein quality of processed melon seed as a component of poultry feed. Nigerian Society for Experimental Biology, 16:80-87.

Pampori, Z.A. 2003. Field cum Laboratory Procedures in Animal Health Care. Daya Publications, New Delhi, India. Pp 172-173.

Randox procedure, 2010. Randox procedure for standard biochemical procedures. Second edition. www.randox.com

Rezende, M. S., Mundim, A. V., Fonseca, B. B., Miranda, R. L., Oliveira, Jr. W. and Lellis, C. G. 2017. Profile of Serum Metabolites and Proteins of Broiler Breeders in Rearing Age. Brazilian Journal of Poultry Science, Vol. 19(4): 583586.

SAS 2008. SAS User's Guide Statistics, SAS Inc. Cary., North Carolina, 2008 edition.

Schmidt, E. M. S., Locatelli-Dittrich, R., Santin, E. and Paulillo, A. C. 2007. Patologia clínica em aves de produção - uma ferramenta para monitorar a sanidade avícola revisão. Archives of Veterinary Science 12(3):9-20. 
Trautwein, J., Chudaske, C., Roser, W. and Dusel, G. 2008. Effect of distilled dried grains with solubles, with or without supplementation of NSP-hydrolysing enzymes on broiler performance. Proceedings of the $10^{\text {th }}$ Tagung Schweine und Geflugelernahrung, Halle/Saale, Germany, pp 123-125.

Toghyani, M., Tohidi, M., Gheisari, A. A. and Tabeidian, S. A. 2010. Performance, immunity, serum biochemical and hematological parameters in broiler chicks fed dietary thyme as alternative for an antibiotic growth promoter. African Journal of Biotechnology, Vol. 9(40), pp. 6819-6825.
Zanu, H. K, Adom, S. O. and AppiahAdu, P. 2012. Response of cockerels to diets containing different levels of sheanut cake. Agricultural Sciences Research Journals Vol. 2(7), pp. 420 -423.

Received: $2^{\text {nd }}$ November, 2020 Accepted: $11^{\text {th }}$ February, 2021 